\title{
EXPERIMENTAL MODELS OF CHARACTERIZATION AND ANALYSIS OF INDUSTRIAL WASTE
}

Lidia Kim, Alina-Maria Muresan, Adriana Cuciureanu, Doina Guta, Madalina Arama, Nicolae Ionut Cristea, Violeta Dediu

National Research and Development Institute for Industrial Ecology ECOIND Bucharest, 7173 Drumul Podu Dambovitei, 060652, Bucharest, Romania, evmt@incdecoind.ro

\begin{abstract}
In the present paper we report, a series of experimental characterization and analysis models that can be applied to industrial waste samples in order to determine the heavy metals within them. During our studies we determined that both preparation and pretreatment of the waste sample are the two most important steps in the analysis process. Therefore, an increased attention was given in using appropriate procedures and methods for preparation and pretreatment. In order to ensure a correct and secure analysis were developed experimental models based on preparation and pretreatment stages and also on organic matrix decomposition method (digestion process with acid mixture under microwave). These experimental models were tested on a series of wastes coming from processing and finishing activities of metal surfaces and other materials. Metal concentration was analyzed by AAS (atomic absorption spectrometry) and XRF (X-ray fluorescence spectrometry). The obtained results proved that the proposed experimental models are suitable for analysis of different types of industrial wastes samples.
\end{abstract}

Keywords: experimental models, heavy metals, industrial waste, microwave digestion

\section{Introduction}

Knowing the waste composition is extremely important because based on it and depending on the waste nature and the hazardous substances content, the environmental contamination degree could be highlighted (Haţegan 2013; Guta et al. 2013). Also, knowing waste composition is important from a managerial point of view, which consists in collecting, transporting, capitalizing and waste disposal activities, as well as in terms of recycling, reuse or treatment (Arama et al. 2015; Arama \& Kim 2016). It is well known that pollution of the natural environment with heavy metals is a universal problem because these metals are not biodegradable and many of them have toxic effects on living organisms and implicitly on human health (Zeng et al. 2016). Considering that most metal analysis techniques allow their determination in aqueous solution, the greatest difficulty and complexity of metal waste analysis is to bring them into a liquid form as an aqueous solution, given that each waste is different depending on the activity or product from which it was generated.

Currently they are many waste categories for which are no available methods of characterization, processing and, implicitly, heavy metal content analysis.

Given the current legislative tasks (Law 21 /2011; GD 856 2002; GD 34 /2005; GO 95 2005; GD 1061 2008), frequent requests come from those who own and / or 


\section{INTERNATIONAL SYMPOSIUM "THE ENVIRONMENT AND THE INDUSTRY", SIMI 2017, PROCEEDINGS BOOK}

manage wastes, regarding their characterization in order to determine the hazardous / non-hazardous character and further including them on waste list, filing the transport forms as well as to determine the type of deposit in which a waste can be accepted (Guta et al. 2013). All this steps involve primarily analytical determinations of waste specific quality indicators, hence the importance of the laboratory analysis quality made on wastes (Puiu \& Cruceru 2016). Equally important is to carry out a correct sampling process and all preliminary operations of the actual waste analysis (packing, storage, preservation, transport, pretreatment etc.) (Stenvall et al. 2013; Dahlén \& Lagerkvist 2008; Van der Sloot \& Kosson 2012; Musee et al. 2008; Guta et al. 2013). In the literature there are presented a series of preparation methods for waste samples in order to determine the heavy metals from them, such as digestion in open systems and closed systems (Mester \& Sturgeon 2003; Qi et al. 2007; Nóbrega \& Donati 2011; Ramanathan \& Ting 2015), combustion (Flores et al. 2007), ultrasonic extraction and solvent dilution (Nelson et al. 2015; Mello et al. 2012).

The paper presents two experimental models for the characterization and analysis of industrial wastes and their application for wastes samples preparation and pretreatment in order to determine heavy metals such as $\mathrm{Cu}, \mathrm{Zn}, \mathrm{Ni}$ and $\mathrm{Pb}$. The study investigated the efficiency of the microwave digestion method by the variation of the oxidation agents and a comparative analysis of waste analysis by AAS and XRF.

\section{Materials and Methods}

The experimental characterization and analysis models were developed based on a series of sample characterization standards (ASRO 2009; ASRO 2013a; ASRO $2013 \mathrm{~b}$ ) and on an analysis protocol used to determine a waste total composition of by analyzing its components and constituents (Hennebert et al. 2013).

This protocol allows the user to obtain adequate information about organic and mineral substances contained within the waste and in the same time the determination of their properties in order to comply with the regulations in force or to ensure the recyclation process.

In Figure 6 and Figure 7, are given two models of preparation and characterization applicable on solid waste and solid-liquid mixture.

Due to the fact that each waste sample analysed was different we were able to consider them as unique tests. Therefore these models had to be adapted to the origin and composition of each individual waste. The models that were described above were applied to four wastes coming from processing and finishing activities of metal surfaces and other materials. The selected waste samples were solid (three of them) and semi-solid (one of them), their description (Figure 8) is given below: 


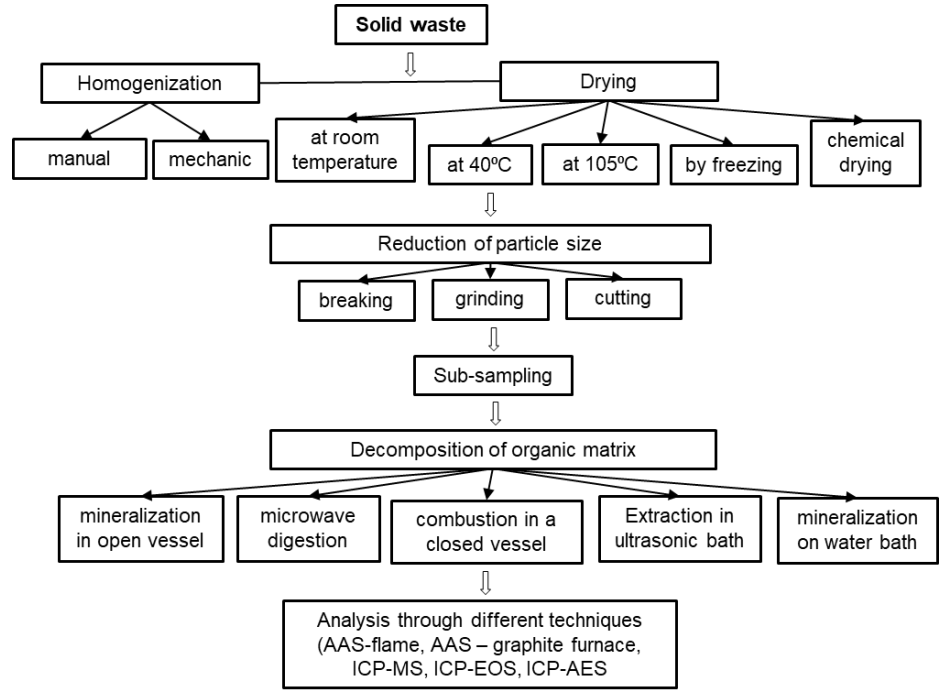

Figure 6. Solid waste characterization scheme

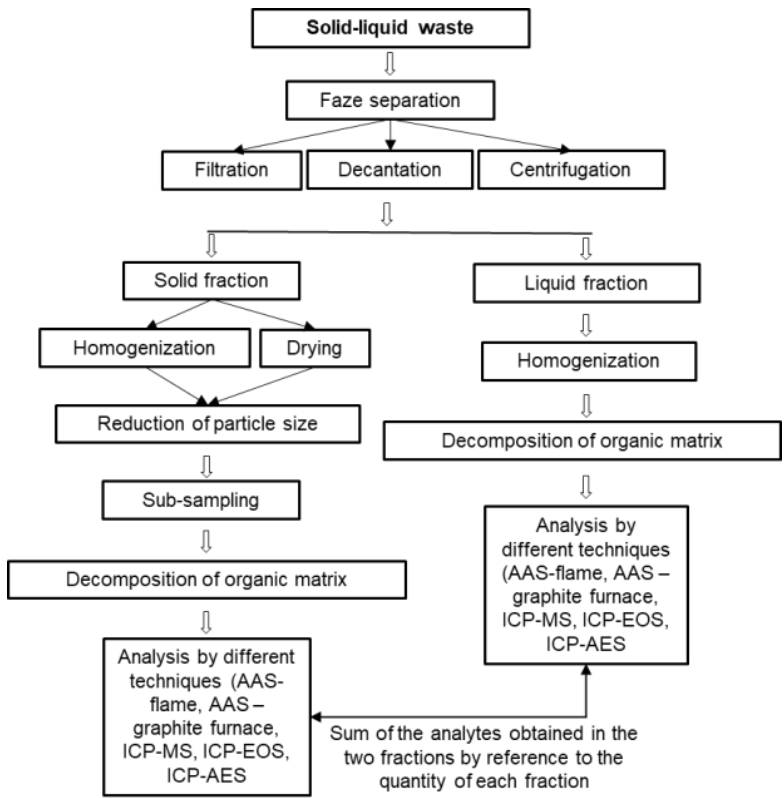

Figure 7. Solid-liquid waste characterization scheme

N1 - Soil and filter cakes containing dangerous substances, waste code $110109 *$ generated from nickel and chrome plating processes; 


\section{INTERNATIONAL SYMPOSIUM "THE ENVIRONMENT AND THE INDUSTRY", SIMI 2017, PROCEEDINGS BOOK}

N2 - Soil and filter cakes containing dangerous substances, waste code $110109 *$ generated from electrochemical milling processes of metal parts using salt baths; D1 - Powder coating waste - generated from the brake pad manufacturing industry; D2 - Paint waste - generated from cleaning or mixing colors during painting process of aluminum profiles in electrostatic field.

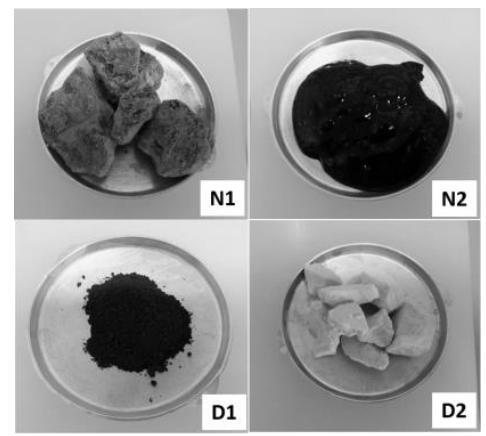

Figure 8. Study types of waste

\section{Preparation of waste samples}

The preparation of waste samples in order to ensure organic matter decomposition was carried out in several stages according to scheme presented in Figure 9.

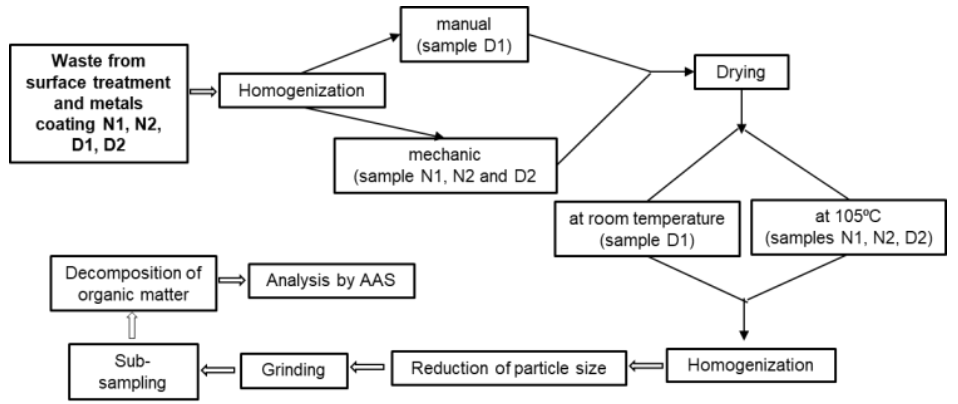

Figure 9. Sample preparation scheme

\section{Organic matter decomposition}

For sample mineralization was used microwave digestion according to the schedule in Table 6. Organic matter digestion was performed using ETHOS UP equipment provided by Milestone Company.

In order to track the mineralization efficiency, the used acids had different concentrations, and they were used separately or in mixture, according to EPA 3052 (EPA 1996) (Table 7). After the mineralization step, the obtained solutions were analysed using a flame atomic absorption spectrometer (AAS) using a calibration curve in the range 0.1 to $0.5 \mathrm{mg} / \mathrm{L}$. The calibration curve was prepared based on monoelement certified reference material (CRMs) solutions having a concentration of 1000 
$\mathrm{mg} / \mathrm{L}$ in $2 \% \mathrm{HNO}_{3}$. All reagents used were of high analytical purity (Merck quality). Each experiment was repeated three times, the final result representing the mean of the three measurements.

Table 6. Microwave program

\begin{tabular}{c|ccc}
\hline \multicolumn{4}{c}{ Microwave digestion program } \\
\hline Steps & $\mathbf{1}$ & $\mathbf{2}$ & $\mathbf{3}$ \\
\hline Temperature $\left({ }^{\circ} \mathrm{C}\right)$ & 100 & 200 & 70 \\
Microwave power $(\%)$ & 1500 & 1500 & 0 \\
Time (minutes) & 15 & 30 & 30 \\
\hline
\end{tabular}

Table 7. Methods of mineralization

\begin{tabular}{|c|c|c|c|}
\hline $\begin{array}{c}\text { Methods of } \\
\text { mineralization }\end{array}$ & Analyte & $\begin{array}{l}\text { Analytical } \\
\text { technique }\end{array}$ & Procedure \\
\hline $\begin{array}{c}\text { Method I. } \\
\mathrm{HNO}_{3}\end{array}$ & $\begin{array}{l}\mathrm{Cu}, \mathrm{Zn}, \\
\mathrm{Ni}, \mathrm{Pb}\end{array}$ & AAS & $\begin{array}{l}0.5 \mathrm{~g} \text { of the sample is introduced into the } \\
\text { digestion cell. Add } 10 \mathrm{~mL} \text { of } \mathrm{HNO}_{3}(65 \%) \text {. }\end{array}$ \\
\hline $\begin{array}{l}\text { Method II. } \\
\mathrm{HNO}_{3}+\mathrm{HCl}\end{array}$ & $\begin{array}{l}\mathrm{Cu}, \mathrm{Zn}, \\
\mathrm{Ni}, \mathrm{Pb}\end{array}$ & AAS & $\begin{array}{l}0.5 \mathrm{~g} \text { of the sample is introduced into the } \\
\text { digestion cell. Add } 3 \mathrm{~mL} \mathrm{HNO}_{3}(65 \%)+7 \\
\mathrm{~mL} \mathrm{HCl} 37 \%(\mathrm{v} / \mathrm{v}) .\end{array}$ \\
\hline $\begin{array}{l}\text { Method III. } \\
\mathrm{HNO}_{3}+\mathrm{H}_{2} \mathrm{O}_{2}\end{array}$ & $\begin{array}{l}\mathrm{Cu}, \mathrm{Zn}, \\
\mathrm{Ni}, \mathrm{Pb}\end{array}$ & AAS & $\begin{array}{l}0.5 \mathrm{~g} \text { of the sample is introduced into the } \\
\text { digestion cell. Add } 6 \mathrm{~mL} \mathrm{HNO}_{3}(65 \%)+4 \\
\mathrm{~mL} \mathrm{H}_{2} \mathrm{O}_{2}(30 \%)(\mathrm{v} / \mathrm{v}) .\end{array}$ \\
\hline $\begin{array}{l}\text { Method IV. } \\
\mathrm{HNO}_{3}+\mathrm{H}_{2} \mathrm{O}_{2} \\
+\mathrm{HCl}\end{array}$ & $\begin{array}{l}\mathrm{Cu}, \mathrm{Zn}, \\
\mathrm{Ni}, \mathrm{Pb}\end{array}$ & AAS & $\begin{array}{l}0.5 \mathrm{~g} \text { of the sample is introduced into the } \\
\text { digestion cell. Add } 4 \mathrm{~mL} \mathrm{HNO}_{3}(65 \%)+4 \\
\mathrm{~mL} \mathrm{H}_{2} \mathrm{O}_{2}(30 \%)+2 \mathrm{~mL} \mathrm{HCl}(37 \%)(\mathrm{v} / \mathrm{v} / \mathrm{v})\end{array}$ \\
\hline
\end{tabular}

After complete digestion, the solutions were filtered through blue strip filter paper (porosity $3 \mu$ ), and filled up to volume of $50 \mathrm{~mL}$ and were measured on AAS, using a calibration curve in the range 0.1 to $0.5 \mathrm{mg} / \mathrm{L}$.

\section{Results and Discussion}

In Fig. 5-8 are presented the results obtained for all types of waste samples analysed. From the obtained results, it is found that the highest concentrations were obtained by applying mineralization method IV (mixture of $\mathrm{HNO}_{3} 65 \%+\mathrm{H}_{2} \mathrm{O}_{2}(30 \%)+\mathrm{HCl}$ $(37 \%)$, even if the concentration differences between the four analysed wastes $(\mathrm{N} 1$, N2, D1, D2) were not very high.

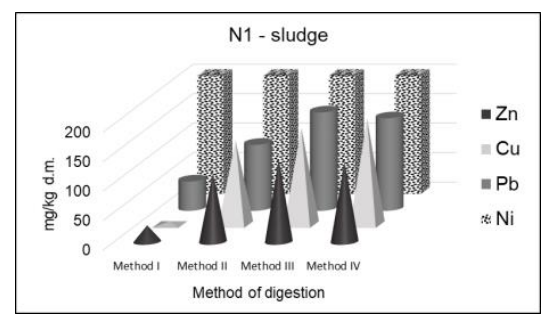

Figure 10. Experimental results for sludge N1

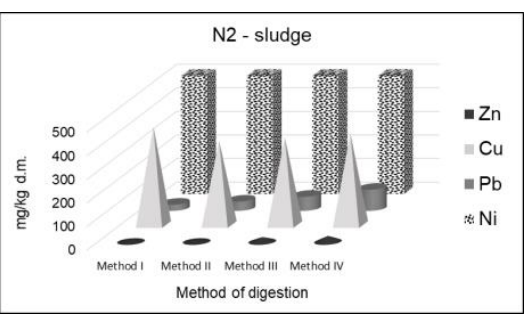

Figure 11. Experimental results for sludge N2 


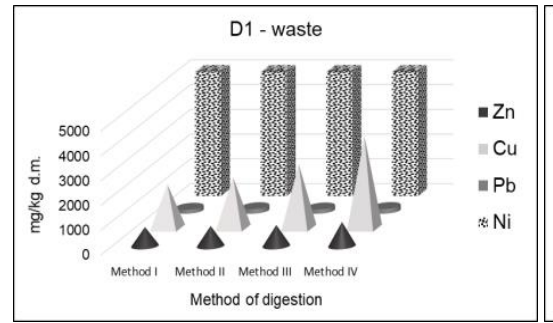

Figure 12. Experimental results for waste D1

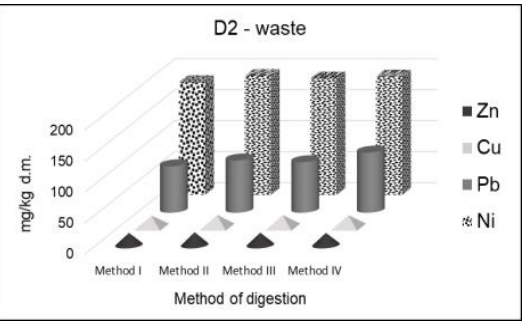

Figure 13. Experimental results for waste D2

The results obtained for the two types of sludge N1 and N2 (sludge and filter cakes containing dangerous substances) cannot be compared, even if analysed sludge are part of the same waste class. Therefore we could conclude that this aspect indicates that each waste has a different composition depending on the mode or processes which led to its generation.

Also there is a clear difference between the appearances of the two sludge: one being a paste, the other in the form of agglomerations. The only similarity between the two waste samples N1 and N2 is nickel loading (27224 mg/kg dry matter (N1) and 5117 $\mathrm{mg} / \mathrm{kg}$ dry matter (N2)), concentrations obtained using method IV.

In terms of analysed metals, the composition of D1 and D2 wastes was different, and we concluded that it depends on their generation process.

For the paint waste sample it is found that the metal concentrations are much lower, indicating that the paint does not accumulate heavy metals in high concentrations.

\section{Comparative study on heavy metals composition in waste samples}

In order to verify the results obtained for all analysed waste samples (four types of waste) using AAS analysis, were carried out comparative studies on X-ray fluorescence spectrometry (XRF) equipment.

XRF analysis were performed using a Rigaku CG analyzer (Rigaku, Japan) equipped with a 50W X-ray source having a Pd anode and secondary $\mathrm{Al}, \mathrm{Mo}, \mathrm{Cu}$ and RX9 targets (highly oriented pyrolytic graphite HOPG polarizer).

The choice of secondary targets was done automatically, depending on the analysed items. Detection was performed using a silicon drift detector (SSD) maintained at optimum temperature via a Peltier system.

This technique does not require all sample preparation operations (operations applied for AAS), but only a part of them such as: drying at $105^{\circ} \mathrm{C}$ and homogenization by means of a mortar and sieving process, the sample being introduced in solid state into the equipment.

Approximately $1 \mathrm{~g}$ of each waste sample was introduced into a polypropylene cup (diameter $32 \mathrm{~mm}$ ) equipped with a Prolene transparent film, after than the sample was analysed.

In order to perform the comparative analysis by the two techniques, the metal concentrations obtained by mineralization method IV were taken into consideration. After comparing the results obtained by the two analytical techniques (Table 8), it is found that for all the analysed waste samples, the obtained concentrations values are comparative, being slightly higher when is used XRF technique. This fact is due to 
the way in which sample are analysed, in XRF technique the interference given by oxidation agents and compound losses resulting from the preparation and pretreatment steps are eliminated.

Table 8. Comparative results obtained through AAS and XRF

\begin{tabular}{cc|cc}
\hline Waste sample & Metal & $\begin{array}{c}\text { VRF } \\
\text { technique } \\
\left(\mathrm{mg} / \mathrm{kg} \mathrm{d.m.}{ }^{*}\right)\end{array}$ & $\begin{array}{c}\text { VAS } \\
\text { Method IV } \\
(\mathrm{mg} / \mathrm{kg} \mathrm{d.m} .)\end{array}$ \\
\cline { 3 - 4 } N1 - Soil and filter cakes containing & $\mathrm{Zn}$ & 217 & 136 \\
dangerous substances, & $\mathrm{Ni}$ & 30057 & 27224 \\
waste code 11 01 09* & $\mathrm{Cu}$ & 235 & 180 \\
\hline \multirow{2}{*}{ N2 - Soil and filter cakes containing } & $\mathrm{Pb}$ & 174 & 157 \\
dangerous substances, & $\mathrm{Zn}$ & 33.7 & 24.4 \\
waste code 11 01 09* & $\mathrm{Ni}$ & 5653 & 5117 \\
& $\mathrm{Cu}$ & 444 & 387 \\
& $\mathrm{~Pb}$ & 106 & 89.3 \\
\hline \multirow{2}{*}{ D1 - Powder coating waste } & $\mathrm{Zn}$ & 85767 & 189 \\
& $\mathrm{Ni}$ & 197 & 975 \\
& $\mathrm{Cu}$ & 1117 & 3713 \\
\hline \multirow{2}{*}{ D2 - Paint waste } & $\mathrm{Pb}$ & 4343 & 191 \\
& $\mathrm{Zn}$ & 207 & 19.6 \\
& $\mathrm{Ni}$ & 112 & 19.3 \\
\hline
\end{tabular}

"Dry matter

\section{Conclusions}

From the obtained results it is found that even if there are no very high concentration differences between the four analysed wastes (N1, N2, D1, D2), the highest concentrations were obtained by applying method IV in digestion step. Metal concentrations obtained through this method were also verified using XRF analysis technique. The results obtained applying both analytical methods (AAS and XRF) are comparative and they highlight the fact that the models applied in samples preparation of are suitable for the characterization and analysis of these categories of wastes.

\section{Acknowledgements}

This paper is based on the analysis methods developed in the project PN 16250107 (Development and implementation of methods for analysis and characterization of industrial wastes), being funded by Romanian National Authority for Scientific Research.

\section{References}

Arama, MG \& Kim, L 2016, 'Using waste hierarchy concept for optimizing the management of the waste disposal amount and implicitly of the possible ecological risk', International Symposium "The Environment and The Industry”, National Research and Development Institute for Industrial Ecology, Bucharest, pp. 66-72.

Arama, MG, Pascu, LF \& Guta, D 2015, 'Decision model based on analytical hierarchy process for managing the environmental risks within the environmental management systems', International Symposium "The 
Environment and The Industry”, National Research and Development Institute for Industrial Ecology, Bucharest, pp. 118-123.

ASRO 2009, SR CEN/TR 15310, part 1-5 Characterization of waste. Sampling of waste materials.

ASRO 2013a, SR EN 16174 Sludge, treated biowaste and soil - Digestion of aqua regia soluble fractions of elements.

ASRO 2013b, SR EN 16179 Sludge, treated biowaste and soil - Guidance for sample pretreatment.

Dahlén, L \& Lagerkvist, A 2008, 'Methods for household waste composition studies'. Waste Management, vol. 28, no. 7, pp. 1100-1112.

EPA 1996, Method 3052. Microwave assisted acid digestion of siliceous and organically based matrices.

Flores, ÉM, Barin, JS, Mesko, MF \& Knapp, G 2007, 'Sample preparation techniques based on combustion reactions in closed vessels - a brief overview and recent applications'. Spectrochimica Acta Part B: Atomic Spectroscopy, vol. 62, no. 9, pp. 1051-1064.

GD 349 2005, Government Decision no. 349 on the storage of wastes, Romanian Official Monitor no. 394 from 10th May, 2005.

GD 856 2002, Government Decision no. 856 - regarding the evidence of waste management and approved list of waste including hazardous waste, Romanian Official Monitor no. 659 from 5th September, 2002.

GD 1061 2008, Government Decision no. 1061 on hazardous and non-hazardous waste transport in Romania, Romanian Official Monitor no. 672 from 30th September, 2008.

GO 95 2005, Government Order no. 95 establishing acceptance criteria and preliminary procedures for the acceptance of waste storage and the national list of waste accepted in each class of landfill, Romanian Official Monitor no. 194 from 8th March, 2005.

Guta, D, Batrinescu, G \& Cuciureanu, A 2013, 'Determining the dangerousness of waste', International Symposium "The Environment and The Industry", National Research and Development Institute for Industrial Ecology, Bucharest, pp. 243-252.

Haţegan, R-M 2013, Monitorizarea metalelor prioritarelprioritar periculoase prin tehnici spectrale moderne în managementul deşeurilor, $\mathrm{PhD}$ thesis, BabesBolyai University.

Hennebert, P, Papin, A, Padox, J-M \& Hasebrouck, B 2013, 'The evaluation of an analytical protocol for the determination of substances in waste for hazard classification'. Waste management, vol. 33, no. 7, pp. 1577-1588.

Law 211 2011, Law no. 211 on the regime of waste, Romanian Official Monitor no. 837 from 25th November, 2011.

Mello, PA, Pereira, JS, Mesko, MF, Barin, JS \& Flores, EM 2012, 'Sample preparation methods for subsequent determination of metals and non-metals in crude oil A review'. Analytica chimica acta, vol. 746, no. pp. 15-36.

Mester, Z \& Sturgeon, RE 2003, Sample preparation for trace element analysis, Elsevier, Canada.

Musee, N, Aldrich, C \& Lorenzen, L 2008, 'New methodology for hazardous waste classification using fuzzy set theory: Part II. Intelligent decision support system'. Journal of hazardous materials, vol. 157, no. 1, pp. 94-105. 
Nelson, J, Gilleland, G, Poirier, L, Leong, D, Hajdu, P \& Lopez-Linares, F 2015, 'Elemental analysis of crude oils using microwave plasma atomic emission spectroscopy'. Energy \& Fuels, vol. 29, no. 9, pp. 5587-5594.

Nóbrega, JA \& Donati, GL 2011, Microwave-Assisted Sample Preparation for Spectrochemistry, Wiley, USA.

Puiu, D \& Cruceru, LV 2016, 'Guidance tool for waste analysis in an accredited laboratory', International Symposium "The Environment and the Industry", National Research and Development Institute for Industrial Ecology, Bucharest, pp. 81-88.

Qi, L, Zhou, M-F, Wang, CY \& Sun, M 2007, 'Evaluation of a technique for determining Re and PGEs in geological samples by ICP-MS coupled with a modified Carius tube digestion'. Geochemical Journal, vol. 41, no. 6, pp. 407414.

Ramanathan, T \& Ting, Y-P 2015, 'Selection of wet digestion methods for metal quantification in hazardous solid wastes'. Journal of Environmental Chemical Engineering, vol. 3, no. 3, pp. 1459-1467.

Stenvall, E, Tostar, S, Boldizar, A, Foreman, MRS \& Möller, K 2013, 'An analysis of the composition and metal contamination of plastics from waste electrical and electronic equipment (WEEE)'. Waste management, vol. 33, no. 4, pp. 915-922.

Van der Sloot, H \& Kosson, D 2012, 'Use of characterisation leaching tests and associated modelling tools in assessing the hazardous nature of wastes'. Journal of hazardous materials, vol. 207, pp. 36-43.

Zeng, X, Xu, X, Boezen, HM \& Huo, X 2016, 'Children with health impairments by heavy metals in an e-waste recycling area'. Chemosphere, vol. 148, pp. 408-415. 